OPEN ACCESS

Edited by:

Ren-Shan Ge,

Wenzhou Medical University, China

Reviewed by:

Alberto Ferlin

Università degli Studi di Brescia, Italy

Terje Svingen,

National Food Institute, Technical University of Denmark, Denmark

*Correspondence:

Nafis A. Rahman

nafis.rahman@utu.fi

Specialty section:

This article was submitted to Reproduction,

a section of the journal

Frontiers in Endocrinology

Received: 09 October 2018

Accepted: 16 January 2019

Published: 04 February 2019

Citation:

Chrusciel M, Ponikwicka-Tyszko D, Wolczynski S, Huhtaniemi I and

Rahman NA (2019) Extragonadal

FSHR Expression and Function-Is it

Real? Front. Endocrinol. 10:32.

doi: 10.3389/fendo.2019.00032

\section{Extragonadal FSHR Expression and Function-Is It Real?}

\author{
Marcin Chrusciel ${ }^{1}$, Donata Ponikwicka-Tyszko ${ }^{2}$, Slawomir Wolczynski ${ }^{2,3}$, \\ Ilpo Huhtaniemi ${ }^{1,4}$ and Nafis A. Rahman ${ }^{1,3 *}$ \\ 1 Institute of Biomedicine, Research Centre for Integrative Physiology and Pharmacology, University of Turku, Turku, Finland, \\ ${ }^{2}$ Institute of Animal Reproduction and Food Research, Polish Academy of Sciences, Olsztyn, Poland, ${ }^{3}$ Department of \\ Reproduction and Gynecological Endocrinology, Medical University of Bialystok, Bialystok, Poland, ${ }^{4}$ Institute of Reproductive \\ and Developmental Biology, Imperial College London, London, United Kingdom
}

Expression of the follicle-stimulating hormone receptor (FSHR), besides gonadal tissues, has recently been detected in several extragonadal normal and tumorous tissues, including different types of primary and metastatic cancer and tumor vessel endothelial cells (TVEC). The suggested FSH actions in extragonadal tissues include promotion of angiogenesis, myometrial contractility, skeletal integrity, and adipose tissue accumulation. Non-malignant cells within cancer tissue have been shown to be devoid of FSHR expression, which implies a potential role of FSHR as a diagnostic, prognostic, or even a therapeutic tool. There are shared issues between several of the published reports questioning the validity of some of the conclusion. Firstly, protein expression of FSHR was performed solely with immunohistochemistry $(\mathrm{IHC})$ using either an unavailable "in house" FSHR323 monoclonal antibody or poorly validated polyclonal antibodies, usually without additional methodological quality control and confirmations. Secondly, there is discrepancy between the hardly traceable or absent FSHR gene amplification/transcript data and non-reciprocal strong FSHR protein immunoreactivity. Thirdly, the pharmacological high doses of recombinant FSH used in in vitro studies also jeopardizes the physiological or pathophysiological meaning of the findings. We performed in this review a critical analysis of the results presenting extragonadal expression of FSHR and FSH action, and provide a rationale for the validation of the reported results using additional more accurate and sensitive supplemental methods, including in vivo models and proper positive and negative controls.

Keywords: FSH, FSHR, extragonadal expression, cancer cells, tumor vessel cells

\section{INTRODUCTION}

Follicle-stimulating hormone (FSH) is synthesized by the anterior pituitary gonadotroph cells, and it plays a critical role in controlling male and female gonadal function $(1,2)$. FSH acts through its specific receptor (FSHR), a member of the highly conserved family of class A G-protein-coupled receptors (GPCR) (3). In females, FSHR is expressed in granulosa cells and it regulates the maturation of Graafian follicles, granulosa cell proliferation and estrogen production (4). In males, FSHR is expressed in testicular Sertoli cells and it regulates their metabolic functions necessary for proper spermatogenesis and germ cell survival (5). FSHR activation may trigger a number of intracellular signaling pathways that will be activated in parallel or sequentially $(6,7)$. The canonical 
Gs $\alpha /$ cAMP/PKA signaling pathway, a key effector mechanism of FSH action, activates the cAMP response element-binding protein that modulates gene transcription $(6,7)$. However, in recent years, it has been shown that also Gas-independent pathways, such as the PI3K/PIP3-AKT/mTOR pathway, $\beta$ arrestin-dependent pathway or interaction of FSHR with PPL1, FoxO1a, and 14-3-3 $\tau$, are involved in FSH-dependent cellular responses [reviewed in (8)].

Recent studies have suggested the expression of FSHR in many normal extragonadal tissues, as well as in the tumors and tumor vessel endothelial cells (TVECs) (summarized in Table 1B). Considering these new findings on extragonadal FSHR expression, a potential role for FSHR as a diagnostic, prognostic and therapeutic tool has been suggested. However, when some of the extragonadal FSHR findings have been revisited no FSHR transcript (by in situ hybridization RNAscope study) or gene amplification (by TaqMan probes-based qPCR) has been found in the tissues presenting with FSHR protein immunoreactivity by IHC staining $(9,10,16,17)$.

This review will summarize and discuss the most important extragonadal FSHR expression findings and highlights some of the caveats involved in these data. We offer our remarks in constructive spirit, and hope they will be found useful in future research on the intriguing topic of extragonadal FSH/FSHR action.

\section{DISCREPANCY BETWEEN FSHR mRNA AND PROTEIN EXPRESSION LEVELS}

Surprisingly, in many studies, the high and clearly abundant FSHR expression at protein levels by immunohistochemistry or immunofluorescence was not associated with clear FSHR mRNA amplification $(9,11,13)$. Nested polymerase chain reaction with gene-specific revers transcription, instead of traditional PCR, was needed to detect FSHR expression in umbilical cord, placenta, and uterus $(9,11,13)$. This could indicate a short turnover time and/or rapid degradation of the FSHR transcripts or, not totally unlikely, nonspecific IHC staining results. Moreover, the lack of sequencing data of PCR products reduces the reliability of mRNA detection $(9,11,13)$. In normal testis, there is $\sim 0.04 \mathrm{pg}$ of FSHR transcripts per $\mu \mathrm{g}$ total RNA (43), whereas human ovary contains a small amount of endogenous FSHR protein $(0.054 \mathrm{fmol} / \mathrm{mg}$ of total protein) (44), and thus its detection by Western Blot might be challenging (45). One explanation could be that FSHR mRNA turnover in extragonadal tissues is much faster than in gonads? Most likely not, considering that in mammals long half-life for RNAs is $t_{(1 / 2)} \geq 4 \mathrm{~h}$ (e.g., housekeeping genes) and a short halflife for RNAs is $t_{(1 / 2)}<4 \mathrm{~h}$ (regulatory genes); thus we should still be able to detect FSHR mRNA at a level relevant to protein levels (46).

\section{ANTI-FSHR ANTIBODIES}

Antibodies are an essential tool for determining cellular protein localization and expression. However, the commercially available monoclonal and polyclonal anti-FSHR antibodies have been poorly or not at all validated. Basic information on selected popular FSHR antibodies is listed in Table 1A. The specificity of two frequently used antibodies, sc-7798 and sc-13935, from Santa Cruz Biotechnology, has been recently revisited (47). In a comprehensive study, the authors compared these antibodies with FSHR323 (44) and two potential therapeutic anti-hFSHRs Ylanthia ${ }^{\circledR}$ antibodies (Y010913, Y010916) for their suitability in IHC detection of FSHR expression in various tissues (47). Specificity of all antibodies was tested by their binding to native hFSHR from different sources and by IHC on paraffin-embedded Flp-In Chinese hamster ovary cells transfected with FSHR (47). Unfortunately, human ovary or testis tissues were not examined, which would have served as proper positive controls (47). The study showed that only the FSHR323 antibody was suitable for target validation of hFSHR in an IHC setting. Furthermore, the authors confirmed their earlier reports on specific overexpression of FSHR in peripheral tumor blood vessels but could not repeat the previously reported FSHR overexpression in ovarian and prostate cancer cells $(24,25,33,47)$.

From a rational point of study design, testing the specificity of FSHR antibodies using (transfected) cancer cell lines or extragonadal tissues cannot be considered sufficient. The most suitable tissues for the validation of specificity of reproducibility of an anti-FSHR antibody should be the human ovary and testis, the only tissues with undisputable FSHR expression. IHC for FSHR should also be tested on FSHR-negative control tissues. The FSHR323 antibody (44), suggested to be the most specific and reproducible, unfortunately has the major disadvantage of not being available either from the laboratory of its origin or commercially. The hybridoma cell line producing FSHR323 antibodies was removed from the American Type Culture Collection selection shortly after the milestone paper on FSHR expression in TVECs (26) was published in 2010, which created a major obstacle for independent validation of the recent studies on non-gonadal FSHR expression (26). If the authors/owners of this FSHR323 antibody are confident of its efficacy in detection of FSHR, they should make it available for other investigators, e.g., by re-depositing the hybridoma cell line to ATCC, so that independent verification of their data would become possible.

\section{FSHR IN NORMAL EXTRAGONADAL TISSUES}

Recent studies on FSHR localization have suggested its expression in many normal extragonadal tissues including umbilical vein, vessel smooth muscle cells (9), placenta and placental endothelial cells (12), fallopian tube (11), myometrium, endometrial stromal cells, endometrial glandular epithelium (16, $17)$, liver (48) bone osteoclasts $(20,49)$, and monocytes $(50,51)$ (Table 1B).

\section{PLACENTA, UMBILICAL CORD VESSELS, AND HUMAN UMBILICAL VEIN ENDOTHELIAL CELLS (HUVECs)}

Human placenta and umbilical cord express FSHR, and these reports proposed that the expression is functional (details below) $(9,11)$. FSHR was found in the endothelial cells of the fetal 
TABLE 1A | Basic information on several commonly used FSHR antibodies for protein localization.

\begin{tabular}{|c|c|c|c|c|}
\hline Antibody & Catalog number & Description & Targeted part of the protein & Producer \\
\hline FSHR323 & & Mouse monoclonal & N-terminal extracellular domain of human FSHR & Commercially unavailable \\
\hline FSHR190 & & Mouse monoclonal & $\mathrm{N}$-terminal extracellular domain of human FSHR & Commercially unavailable \\
\hline FSHR225 & & Mouse monoclonal & N-terminal extracellular domain of human FSHR & Commercially unavailable \\
\hline FSHR18 & CRL-2688 & Mouse monoclonal & N-terminal extracellular domain of human FSHR & ATCC \\
\hline Anti-FSHR & ab219312 & Mouse monoclonal & $\begin{array}{l}\text { Recombinant full length protein corresponding } \\
\text { to human FSHR }\end{array}$ & Abcam \\
\hline Anti-FSHR & LS-A4004 & Rabbit polyclonal & N-terminal extracellular domain of human FSHR & LifeSpan BioSciences \\
\hline FSHR H-190 & sc-13935 & Rabbit polyclonal & $\begin{array}{l}\text { Raised against amino acids } 1-190 \text { of human } \\
\text { FSHR }\end{array}$ & Santa Cruz Biotechnology \\
\hline FSHR N-20 & sc-7798 & Goat polyclonal & $\begin{array}{l}\text { Raised against a peptide mapping near the } \\
\text { N-terminus of human FSHR }\end{array}$ & Santa Cruz Biotechnology \\
\hline Anti-FSHR & & Rabbit monoclonal & & Chemicon \\
\hline Anti-FSHR & & & & Zymed \\
\hline Anti-FSHR & LS-C120589 & Rabbit polyclonal & $\begin{array}{l}\text { Synthetic peptide from human FSHR. (AA } \\
\text { Range: } 278-327 \text { ) }\end{array}$ & Lifespan Biosciences \\
\hline Anti-FSHR & $\begin{array}{l}\text { Y010913, } \\
\text { Y010916 }\end{array}$ & Anti-human & $\begin{array}{l}\text { Two different peptides of the hFSHR } \\
\text { extracellular domain (aa295-332) }\end{array}$ & Commercially unavailable \\
\hline
\end{tabular}

vasculature within the chorionic villi and villous stromal cells from 8 to 10 week of gestation until term, but not in trophoblast cells (11). In human umbilical cord, the location of FSHR was suggested in Wharton's jelly, and endothelial and smooth muscle cells of the vessels (9). Expression of a splice variant lacking exon 9 was detected in primary HUVECs (9).

Further functional studies showed that FSH-stimulated HUVECs responded with AKT activation, but not with cAMP production (9). HUVECs stimulated with a high pharmacological dose of $\mathrm{rhFSH}(600 \mu \mathrm{g} / \mathrm{L}$, equals to $81.86 \mathrm{IU} / \mathrm{L})$ induced significantly tube formation, wound healing, cell migration and proliferation, nitric oxide production and cell survival (9). This prompted the authors to propose that HUVECs express "functional" FSHR expression and that the FSH-FSHR activation promotes angiogenesis as effectively as the potent wellcharacterized angiogenic factor VEGF (9). However, opposite results were published by our group upon revisiting the same study concept and experiments (10). In this latter study, neither FSHR expression nor rhFSH stimulation of freshly isolated HUVECs could be shown (10). In our study, FSHR expression was analyzed with two kits for reverse transcription and qPCR systems, and both gave negative results for HUVECs and an immortalized HUVEC cell line (HUV-ST) (10). The PCR products from the positive control samples were sequenced in order to reconfirm their fidelity, which was not done in the earlier study (9). Numerous methodological uncertainties [presented in detail in (10)], made the results of the previous study hard to interpret and could explain the difference between these two studies (10). Consequently, our data (10) do not support the novel concept that FSH-FSHR activation is involved in the placental vasculature and its angiogenic process (11-13). Results showing that Fshr/FSHR is essential for normal angiogenesis of the fetal placental vasculature (12) are also contradictory because both males and females with inactivating FSHR mutations, thus obligatorily devoid of functional FSHR in their placenta, appear to develop normally in utero (52). Thus, caution is needed to interpret the existing data on the FSH-FSHR activation in placental vasculature and their proangiogenic process, and the functional expression of FSHR in HUVECs still remains a subject of uncertainty.

\section{UTERUS (ENDOMETRIUM AND MYOMETRIUM)}

Several studies suggest that FSHR is expressed in uterine tissues $(11,15-18,53)$. One study appeared to detect positive FSHR signal in the endothelial cells of myometrium vessels and arterial smooth muscle of the normal non-pregnant myometrium, whereas signal in myometrial muscle fibers was weak or only traceable (11). Furthermore, FSHR staining was detected in the endothelial cells, arterial smooth muscle and muscle fibers of myometrium during pregnancy (11); however, the study group was small $(n=3)$. They also showed through PCR analysis that human myometrium from term pregnancy expresses fulllength FSHR mRNA, but the PCR product were not sequenced to reconfirm their fidelity (11). In another study, in term pregnancy non-laboring myometrium, FSH increased contractile activity, but the effects was observed only at supraphysiological doses of $100-1,000 \mu \mathrm{g} / \mathrm{L}(136.43-1364.25 \mathrm{IU} / \mathrm{L})$ (13). In contrast to findings of the former study (11), another recent study did not detect FSHR protein or FSHR transcripts in normal human myometrium (16).

Intriguingly, women with inactivating FSHR mutation, thus lacking both gonadal and extragondal FSHR, can maintain normal pregnancy until term following ovum donation, thus undermining the functional importance of extragonadal FSH action (54).

In human endometrial epithelial and stromal cells, cycledependent expression of FSHR was shown, and FSHR expression 
TABLE 1B | Summary of studies presenting FSHR expression and FSH action in extragonadal normal and malignant tissues.

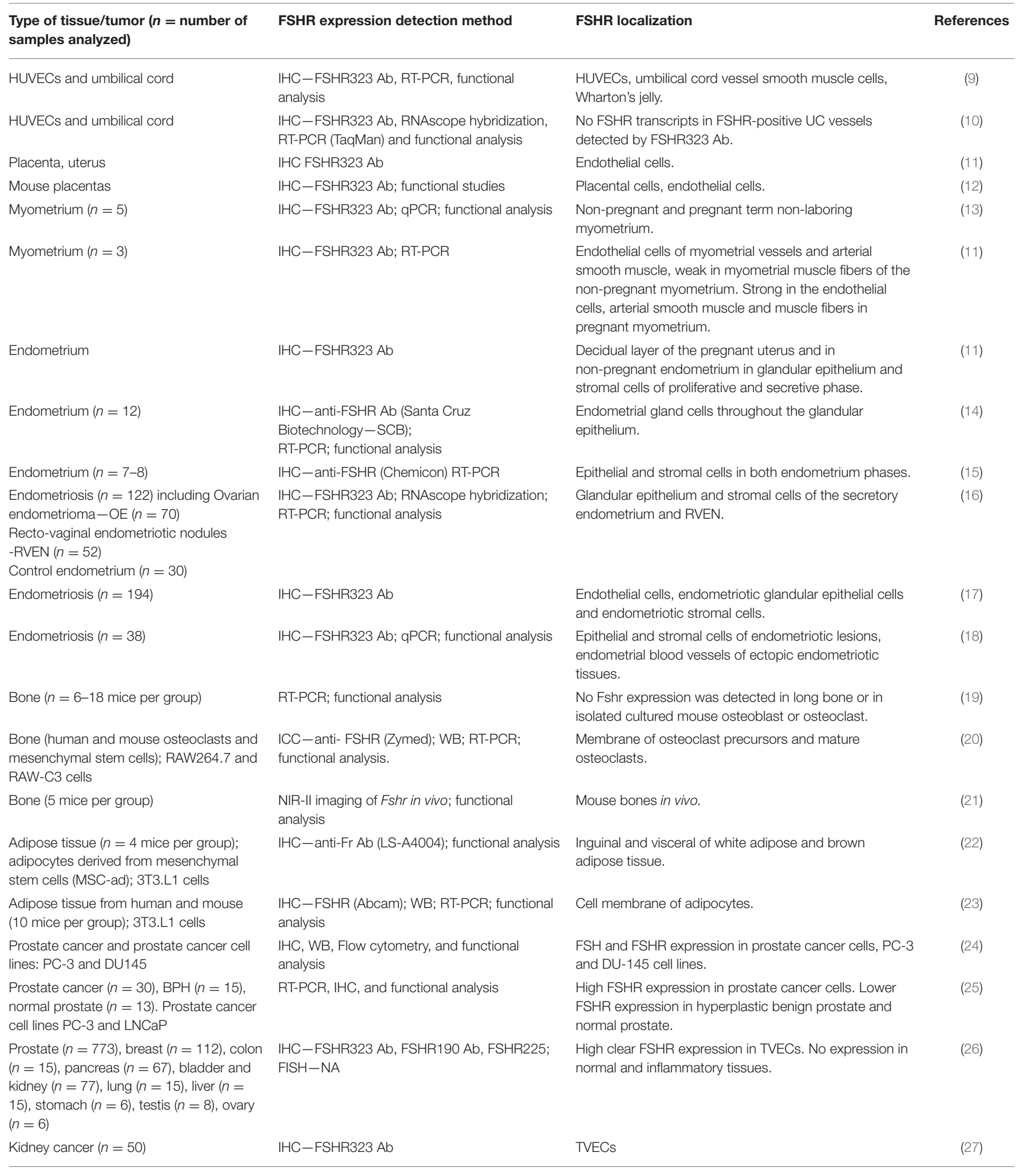


TABLE 1B | Continued

\begin{tabular}{|c|c|c|c|}
\hline $\begin{array}{l}\text { Type of tissue/tumor ( } n=\text { number of } \\
\text { samples analyzed) }\end{array}$ & FSHR expression detection method & FSHR localization & References \\
\hline $\begin{array}{l}\text { Primary tumors and metastases: prostate } \\
(n=76), \text { lung }(n=46), \text { breast }(n=42) \\
\text { colon }(n=34), \text { kidney }(n=5)\end{array}$ & IHC-FSHR323 Ab & TVECs & $(28)$ \\
\hline Breast cancer $(n=83)$ & IHC-FSHR323 Ab & TVECS & $(29)$ \\
\hline Ovarian tumors (EOC, $n=156$ ) & $\mathrm{IHC}, \mathrm{Ab} N \mathrm{NA}$ & $\begin{array}{l}\text { FSHR is expressed in ovarian tumors ( } 64.3 \% \text { analyzed } \\
\text { samples). }\end{array}$ & $(30)$ \\
\hline Ovarian tumors (EOC, $n=153$ ) & $\Vdash \mathrm{HC}, \mathrm{Ab} \mathrm{NA}$ & $\begin{array}{l}\text { Her- } 2 \text { can be a negative prognosticator only in FSHR } \\
\text { negative EOC cases. }\end{array}$ & $(31)$ \\
\hline Ovarian cancer-in vitro study & $\begin{array}{l}\text { Functional studies on HO8910 and HEY cell } \\
\text { lines }\end{array}$ & $\begin{array}{l}\text { FSH induced the epithelial-mesenchymal transition of } \\
\text { ovarian cancer cells through the FSHR-PI3K/Akt-Snail } \\
\text { signaling pathway. }\end{array}$ & $(32)$ \\
\hline Ovarian cancer $(n=77)$ & $\begin{array}{l}\text { IHC, FSHR18 Ab, WB, FSHR18 Ab, qPCR, } \\
\text { TaqMan FSHR probe }\end{array}$ & $\begin{array}{l}\text { Gynecologic malignancies of different histological types, } \\
\text { but not in non-ovarian healthy tissues. }\end{array}$ & (33) \\
\hline Primary rhabdomyosarcoma $(n=58)$ & RT-PCR; functional analysis in vitro & Rhabdomyosarcoma cell lines and primary lesions. & (34) \\
\hline Neuroendocrine tumors $(n=14)$ & IHC-FSHR (sc-13935), SCB & $50 \%$ of TVECs and majority of tumor cells. & (35) \\
\hline $\begin{array}{l}\text { Pancreatic neuroendocrine tumors }(n= \\
\text { 30) }\end{array}$ & $\begin{array}{l}\text { IHC, IF and WB with FSHR (H-190), FSHR } \\
(\mathrm{N}-20), \text { FSHR (N-20) Ab from SCB. }\end{array}$ & Neoplastic cells but no expression in TVECs. & $(36)$ \\
\hline Thyroid neoplasms $(n=44)$ & IHC-FSHR (sc-13935) SCB & Cancer cells and TVECs. & $(37)$ \\
\hline Thyroid neoplasms $(n=36)$ & IHC-FSHR (sc-13935) SCB & Cancer cells and TVECs. & $(38)$ \\
\hline Thyroid neoplasms $(n=312)$ & $\mathrm{HC}, \mathrm{Ab} N \mathrm{NA}$ & $\begin{array}{l}\text { Normal and neoplastic thyroid epithelial cells except } \\
\text { undifferentiated carcinoma. }\end{array}$ & (39) \\
\hline Pituitary adenomas $(n=42)$ & IHC-FSHR (sc-13935) SCB & Adenoma cells and TVECs. & $(40)$ \\
\hline $\begin{array}{l}\text { Pituitary adenomas }(n=28) \\
\text { Adrenal tumors }(n=36)\end{array}$ & IHC-FSHR (sc-13935) SCB & Adenoma cells and TVECs. & $(41)$ \\
\hline $\begin{array}{l}\text { Soft tissue sarcomas }(n=335,11 \\
\text { subtypes) }\end{array}$ & IHC FSHR323 & TVECs and tumor cells. & $(42)$ \\
\hline
\end{tabular}

IHC, immunohistochemistry; NA, not applicable; UC, umbilical cord; TVECs, tumor vessel endothelial cells.

increased during the endometrial secretory phase (15). Furthermore, it has been shown that FSH stimulation induced a decidual phenotype in stromal cells isolated from proliferative phase human endometrium (53). Microarray studies also proposed that FSHR mRNA expression was up-regulated in human endometrial stromal cells decidualized with progesterone and cAMP (55). Moreover, results of our study showed that FSH stimulation upregulated FSHR expression in human endometrial stromal cells undergoing decidualization in vitro (16). It has been shown that during pregnancy, FSHR is expressed in the decidual layer of the pregnant uterus in women (11). FSHR was localized in glandular epithelium and stromal cells of endometrial proliferative and secretive phases. A weak, mainly basolateral FSHR expression was localized in the microvascular endothelium of the normal proliferative endometrium (17). Our group confirmed FSHR expression at mRNA and protein levels in glandular epithelium and stromal cells of normal human secretive endometrium, but not in the proliferative endometrium (16). A very recent study also proposed the functionality of FSHR expression in human endometrium, as endometrial tissue produced cAMP upon FSHR stimulation (14). It seems that FSHR expression in human endometrium, mainly in secretive phase could be functional, but the concept that FSH/FSHR signaling may induce human endometrial stromal cell decidualization requires further evidence.

\section{ADIPOSE TISSUE/OBESITY}

The rise of FSH level in menopausal women is associated with increased visceral adiposity, and decreased bone density and energy expenditure (56). In human and mouse fat tissues and adipocytes, FSHR expression at mRNA and protein levels has been reported (23). Recently, Liu et al. published that blockage of FSH signaling with a specific polyclonal FSH antibody potentially activated brown/beige fat thermogenesis and thereafter reduced the total fat, subcutaneous fat and visceral fat volume induced by high-fat diet in wild-type mice (22). This antibody also reduced adiposity in ovariectomized mice. Immunostaining analysis showed the presence of FSHR in inguinal and visceral white adipose tissues and also in brown adipose tissues in mice. However, this study lacks the proper negative and positive (testis or ovary) tissue controls to confirm the specificity of the used FSHR antibody. To reconfirm the Fshr expression in adipocytes, the authors also sequenced full-length Fshr cDNA from primary mouse mesenchymal stem cells derived from ear lobes and mouse adipocyte-like 3T3.L1 cells (22). However, even though the expression profile of many genes was shown in white and brown adipose tissue in mice in this study, surprisingly no data on Fshr at mRNA levels was reported in those tissues. For proper FSHR expression assessment, the same tissues/cells should be used for both gene expression and protein analysis. Moreover, 
they showed by immunoprecipitation assay that their established FSH antibody binds to FSH $\beta$, but the study lacks data on direct evidence for FSH binding to adipocyte FSHR (22). Another group of treatment with GnRH antagonists to block the gonadotropins (FSH) would have strengthened the findings. The most intriguing part of this FSH antibody-based data is that it contradicts with data from mice and humans using GnRH agonists/antagonists, where the endpoint is the same-blockage of gonadotropins. We did not observe any loss of body fat in transgenic mice treated by $\mathrm{GnRH}$ antagonist in conjunction with gonadal or adrenocortical tumor treatment $(57,58)$. FSH suppression concomitant with that of gonadal steroids did not decrease body fat in a clinical study on men (59). This group (22) has developed now an HF2 monoclonal antibody that targets human FSH $\beta$, but no reports in humans have been shown yet (60).

\section{BONE MASS/OSTEOPOROSIS}

It has been proposed that enhanced postmenopausal bone resorption is caused not by estrogen deficiency, but by increased FSH level (61). Direct effect of FSH-FHSR on bone loss in mice has recently been shown (20-22). FSHR was localized in mouse and human osteoclasts and mesenchymal stem cells $(20,62)$. The latest study reported that blockage of FSH action by a specific monoclonal antibody targeting FSH $\beta$ subunit increased bone mass and stimulated new bone formation by osteoblasts in mice (22). Moreover, osteoclastogenesis and expression of osteoclastspecific genes, and matrix metalloproteinase-9, were reduced after attenuation of FSH action (21). The authors showed the presence of FSHR in mouse bones only in vivo, through a specific binding of the fluorescently labeled FSH with near-infrared II fluorophore to FSHR (21). They did not perform any qPCR, immunohistochemistry or Western Blot analysis to demonstrate and/or directly localize FSHR expression in bone. Furthermore, as in the study of FSH action in adipocytes, there is no data showing direct FSH binding to FSHR in bone cells $(21,22)$.

Human studies are not able to replicate the data from the mouse models mentioned above. A direct interventional study showed that FSH does not regulate bone loss in postmenopausal women (63). Suppression of FSH secretion by GnRH agonist did not decrease the level of bone resorption markers, but rather tended to increase some of them (63). In addition, in normal adult men, FSH did not affect bone turnover and thus appears not to be an important regulator of skeletal metabolism (64). Another in vivo study in men showed that sex steroids modulate bone resorption independently of FSH action (65). Blockage of androgen action by $\mathrm{GnRH}$ agonist treatment in prostate cancer patients induced increased fracture risk and bone loss, with no positive effect of FSH suppression (66). Moreover, also some mouse studies showed opposite results $(19,67)$, in contrast to the earlier study (20). Furthermore, FSHR knockout mice have reduced bone mass $(20,67)$, and a dose-dependent FSH effects on increased bone mass through an ovary-dependent mechanism in female mice have been observed (19). In male mice FSH impact on bone loss has not been demonstrated (68). Taken together, further studies are needed to determine whether the FSH-FSHR system action in bone resorption is really functional, only speciesspecific, a probable indirect effect of inflammatory cytokines such as tumor necrosis factor $\alpha$ (TNF- $\alpha)$ (69) or an unidentified off-target effect of the FSH antibodies used.

\section{ENDOMETRIOSIS}

Expression of FSHR has also been suggested in endometriosis (16-18). An immunohistochemical study described FSHR localization in the endometriotic glandular and stromal cells of the rectovaginal endometriotic nodules, ovarian endometriotic cysts, and peritoneal endometriotic lesions, as well as with robust vascular FSHR staining (17). Recently, our group showed functional FSHR expression in deep endometriotic lesions, where FSH through FSHR locally up-regulated aromatase expression and induced estrogen production, and FSHR localized at mRNA and protein levels in endometriotic glandular and stromal cells (16). Moreover, the ovarian pattern of differentiation with functional FSH-FSHR system, inducing production of the same steroidogenic cascade as in ovaries has been shown in endometriotic tissues (18) Based on these results, it appears that the expression of FSHR in endometriosis is functional $(16,18)$.

\section{FSHR IN CANCER AND TUMOR VESSEL ENDOTHELIAL CELLS (TVECs)}

A number of studies (summarized in Table 1B) have shown the expression of FSHR in different types of tumor cells suggesting a potential role of FSH in tumorigenesis and suggesting FSHR as a potential target for cancer therapy. FSHR expression was suggested to be present in prostate, ovarian, thyroid, neuroendocrine pancreatic, and pituitary cancer cells and soft tissue sarcomas (Table 1B). A breakthrough in the study of extragonadal FSHR expression was, when the receptor expression was proposed in TVECs of different types of tumors (prostate, breast, colon, pancreas, urinary bladder, kidney, lung, liver, stomach, testis, and ovary), including their metastases (26, 27, 29). In the prostate cancer FSHR-positive arterioles, capillaries and venules (but not lymphatic vessels) were located at the periphery of the tumor core (26). Endothelial cells of the vessels present in normal-appearing tissues at a distance $>10 \mathrm{~mm}$ outside the tumors or normal prostate were FSHR-negative (26). In subsequent studies, endothelial FSHR expression was shown in thyroid and neuroendocrine tumors $(35,37,40)$. Several groups suggested that the FSHR observed in TVECs and cancer cells is functional $(24-26,70-72)$. FSH-stimulated proliferation, migration and invasion was observed in epithelial cancer cells (70). In TUVECs, FSHR mediated the FSH transport, tumor angiogenesis and vascular remodeling $(26,29)$. With regard to cancer cells and TVECs (primary and metastatic), it was suggested that FSHR might serve as a potential cellular marker of different tumors and provide a novel approach for targeted cancer therapy. If extragonadal FSHR expression and function could be proven by additional independent studies in the TVECs, as well as in the cancer cells, the finding would suggest for FSHR a great utility as a biomarker and/or medicinal target. 
This potentially important finding needs further verification by independent studies.

\section{PROPOSALS TO IMPROVE THE QUALITY OF FSHR LOCALIZATION-VALIDATION OF ANTI-FSHR ANTIBODIES}

In light of the information reviewed above, it seems that the data on extragondal FSHR localization often relies on insufficiently verified antibodies, making interpretation of data difficult; more worryingly, to potentially erroneous conclusions. As an additional validation of FSHR IHC, we propose the use of RNAscope in situ hybridization (73) or other similar methods. This novel and sensitive method displays a single-transcript resolution and is now in common use. A set of validated, negative, and positive control probes (for genes with different expression levels), provided by manufacturer confirm the quality of the tissue used for hybridization. Using the FSHR323 antibody (donated to us by Dr. Ghinea), we were able to confirm FSHR expression in umbilical vein endothelial cells at protein level but not by in situ hybridization or qPCR on mRNA levels, leaving the question open why the expression at protein level is not supported by mRNA data (10). Recently it has been shown that endothelial cells and smooth muscle cells of umbilical cord vessels, despite clear FSHR immunoreactivity using FSHR323 antibody (9), did not express FSHR transcripts, even when confirmed by a gel electrophoresis of qPCR products (10). A similar discrepancy was observed in endometriosis samples where FSHR at protein level has been shown in endothelial cells of the endometroid tissue (17), but could not be reproduced by in situ hybridization at mRNA level (16).

\section{IN VIVO AND IN VITRO MODELS TO STUDY EXTRAGONADAL FSH ACTION}

To resolve the controversies of direct FSH action in extragonadal tissues proper in vivo mouse models would be very useful, as well as functional testing on the extragonadal receptors in vitro. Fshr null mice would be a good model for such studies; although these mice exhibit extragonadal defects, data from different scientific groups show contradictory results $(20,67)$. In vitro experiments on primary cell cultures from extragonadal tissues with purported FSHR expression have also yielded contradictory data $(9,10)$. Some in vitro studies could be performed on extragonadal tissue explants, allowing to examine mechanisms without disturbing tissue structure and tissue receptor status (16). However, to explain all inconsistencies in vivo and to prove that the extragonadal FSH-FSHR system is really functional in different extragonadal tissues, its actions should be evaluated through precise gene targeting, e.g., using the genome-editing CRISPR/Cas9-based method (74). Conditional knockout mouse models with tissuespecific deletion of FSHR via Cre-lox technology would allow us to directly analyze the loss of FSH-FSHR action in desired condition or extragonadal tissue type. A transgenic mouse model expressing human FSHR with a green fluorescent protein
(GFP) or any other reporter marker expression under the FSHR promoter/enhancer could be also a very useful tool to track the FSHR expression. Thereafter, all data can be tested in vitro and in vivo with the same system to prove their functionality.

\section{GENDER DIFFERENCES PUTATIVELY AFFECTING THE EXTRAGONADAL FSHR EXPRESSION}

Many of the studies on extragonadal FSHR function were carried out only on women (endometrium, endometriosis, HUVECs etc.) $(9,10,12,17,18)$ or female mice (osteoporosis, bone metabolism, or the FSH action on the myometrium muscle contractions etc.) $(11,13,21,22,63)$ or cells derived from females (for example HUVECs) $(9,10,12)$. Almost the only exception are the human prostate cancer tumor vessel cells or human prostate cancer tissue/cells (24-26). Some studies do not state properly the sex of the individual or sample. One cannot rule out the option that some pathologies (for example osteoporosis or bone metabolism etc.) have strong sex differences and are influenced differently by sex steroids and in general the sexually dimorphic endocrine functions.

\section{CONCLUSIONS}

FSHR expression in extragonadal tissues, despite numerous publications, remains controversial. We suggest a more critical analysis of such data, especially when the localization of FSHR in normal extragonadal and malignant tissues is based only on IHC data, without additional methodological confirmation. We suggest proper validation of antibody specificity and the reproducibility between lots. Unrestricted access to the currently existing non-commercial anti-FSHR antibodies would support the fairness of science. When planning experiments, more attention should be paid to inclusion of proper positive and negative controls. For functional studies, the doses of rhFSH should be standardized and restricted to physiologically meaningful concentrations. A proof of principle in human clinical trial with the monoclonal HF2 FSH blocking antibody with a comparison to a group of patients with $\mathrm{GnRH}$ antagonist is also needed. It is thus probably not yet time to re-write the textbooks with the functional implications of FSH/FSHR in extragonadal tissues or in cancer cells or TVECs. To this end, definitely many more studies are needed.

\section{AUTHOR CONTRIBUTIONS}

MC, DP-T, SW, IH, and NR took part in designing, drafting, and finalizing of this invited review manuscript.

\section{FUNDING}

This work was financially supported by Polish National Science Center grants 2012/05/B/NZ5/01867 (MC) and 2016/23/B/NZ5/01477 (NR). 


\section{REFERENCES}

1. Kaprara A, Huhtaniemi IT. The hypothalamus-pituitary-gonad axis: tales of mice and men. Metabolism (2018) 86:3-17. doi: 10.1016/j.metabol.2017.11.018

2. Baghian A, Jaynes J, Enright F, Kousoulas KG. An amphipathic alphahelical synthetic peptide analogue of melittin inhibits herpes simplex virus1 (HSV-1)-induced cell fusion and virus spread. Peptides (1997) 18:177-83. doi: 10.1016/S0196-9781(96)00290-2

3. Ulloa-Aguirre A, Zarinan T. The follitropin receptor: matching structure and function. Mol Pharmacol. (2016) 90:596-608. doi: 10.1124/mol.116.104398

4. Kumar TR, Wang Y, Lu N, Matzuk MM. Follicle stimulating hormone is required for ovarian follicle maturation but not male fertility. Nat Genet. (1997) 15:201-4. doi: 10.1038/ng0297-201

5. Plant TM, Marshall GR. The functional significance of FSH in spermatogenesis and the control of its secretion in male primates. Endocr Rev. (2001) 22:764-86. doi: 10.1210/edrv.22.6.0446

6. Means AR, MacDougall E, Soderling TR, Corbin JD. Testicular adenosine $3^{\prime}: 5^{\prime}$-monophosphate-dependent protein kinase. Regulation by folliclestimulating hormone. J Biol Chem. (1974) 249:1231-8.

7. Dattatreyamurty B, Figgs LW, Reichert LE. Physical and functional association of follitropin receptors with cholera toxin-sensitive guanine nucleotide-binding protein. J Biol Chem. (1987) 262:11737-45.

8. Gloaguen P, Crépieux P, Heitzler D, Poupon A, Reiter E. Mapping the folliclestimulating hormone-induced signaling networks. Front endocrinol. (2011) 2:45. doi: 10.3389/fendo.2011.00045

9. Stilley JA, Guan R, Duffy DM, Segaloff DL. Signaling through FSH receptors on human umbilical vein endothelial cells promotes angiogenesis. J Clin Endocrinol Metab. (2014) 99:E813-20. doi: 10.1210/jc.2013-3186

10. Stelmaszewska J, Chrusciel M, Doroszko M, Akerfelt M, Ponikwicka-Tyszko D, Nees M, et al. Revisiting the expression and function of follicle-stimulation hormone receptor in human umbilical vein endothelial cells. Sci Rep. (2016) 6:37095. doi: 10.1038/srep37095

11. Stilley JA, Christensen DE, Dahlem KB, Guan R, Santillan DA, England SK, et al. FSH receptor (FSHR) expression in human extragonadal reproductive tissues and the developing placenta, and the impact of its deletion on pregnancy in mice. Biol Reprod. (2014) 91:74. doi: 10.1095/biolreprod.114.118562

12. Stilley JAW, Segaloff DL. Deletion of fetoplacental Fshr inhibits fetal vessel angiogenesis in the mouse placenta. Mol Cell Endocrinol. (2018) 476:79-83. doi: 10.1016/j.mce.2018.04.011

13. Stilley JAW, Guan R, Santillan DA, Mitchell BF, Lamping KG, Segaloff DL. Differential regulation of human and mouse myometrial contractile activity by FSH as a function of FSH receptor density. Biol Reprod. (2016) 95:36. doi: 10.1095/biolreprod.116.141648

14. Sacchi S, Sena P, Degli Esposti C, Lui J, La Marca A. Evidence for expression and functionality of FSH and LH/hCG receptors in human endometrium. $J$ Assist Reprod Genet. (2018) 35:1703-12. doi: 10.1007/s10815-01 8-1248-8

15. La Marca A, Carducci Artenisio A, Stabile G, Rivasi F, Volpe A. Evidence for cycle-dependent expression of follicle-stimulating hormone receptor in human endometrium. Gynecol Endocrinol. (2005) 21:303-6. doi: 10.1080/09513590500402756

16. Ponikwicka-Tyszko D, Chrusciel M, Stelmaszewska J, Bernaczyk P, Sztachelska M, Sidorkiewicz I, et al. Functional expression of FSH receptor in endometriotic lesions. J Clin Endocrinol Metab. (2016) 101:2905-14. doi: 10.1210/jc.2016-1014

17. Robin B, Planeix F, Sastre-Garau X, Pichon C, Olesen TK, Gogusev J, et al. Follicle-stimulating hormone receptor expression in endometriotic lesions and the associated vasculature: an immunohistochemical study. Reprod Sci. (2016) 23:885-91. doi: 10.1177/1933719115623647

18. Fouquet B, Santulli P, Noel JC, Misrahi M. Ovarian-like differentiation in eutopic and ectopic endometrioses with aberrant FSH receptor, INSL3 and GATA4/6 expression. BBA Clin. (2016) 6:143-52. doi: 10.1016/j.bbacli.2016.11.002

19. Allan CM, Kalak R, Dunstan CR, McTavish KJ, Zhou H, Handelsman DJ, et al. Follicle-stimulating hormone increases bone mass in female mice.
Proc Natl Acad Sci USA. (2010) 107:22629-34. doi: 10.1073/pnas.10121 41108

20. Sun L, Peng Y, Sharrow AC, Iqbal J, Zhang Z, Papachristou DJ, et al. FSH directly regulates bone mass. Cell (2006) 125:247-60. doi: 10.1016/j.cell.2006.01.051

21. Ji Y, Liu P, Yuen T, Haider S, He J, Romero R, et al. Epitopespecific monoclonal antibodies to FSHbeta increase bone mass. Proc Natl Acad Sci USA. (2018) 115:2192-7. doi: 10.1073/pnas.17181 44115

22. Liu P, Ji Y, Yuen T, Rendina-Ruedy E, DeMambro VE, Dhawan $\mathrm{S}$, et al. Blocking FSH induces thermogenic adipose tissue and reduces body fat. Nature (2017) 546:107-12. doi: 10.1038/nature 22342

23. Liu XM, Chan HC, Ding GL, Cai J, Song Y, Wang TT, et al. FSH regulates fat accumulation and redistribution in aging through the Galphai/Ca(2+)/CREB pathway. Aging Cell (2015) 14:409-20. doi: 10.1111/acel.12331

24. Ben-Josef E, Yang SY, Ji TH, Bidart JM, Garde SV, Chopra DP, et al. Hormone-refractory prostate cancer cells express functional folliclestimulating hormone receptor (FSHR). J Urol. (1999) 161:970-6. doi: 10.1016/S0022-5347(01)61831-7

25. Mariani S, Salvatori L, Basciani S, Arizzi M, Franco G, Petrangeli E, et al. Expression and cellular localization of follicle-stimulating hormone receptor in normal human prostate, benign prostatic hyperplasia and prostate cancer. J Urol. (2006) 175:2072-7. doi: 10.1016/S0022-5347(06)00273-4

26. Radu A, Pichon C, Camparo P, Antoine M, Allory Y, Couvelard A, et al. Expression of follicle-stimulating hormone receptor in tumor blood vessels. N Engl J Med. (2010) 363:1621-30. doi: 10.1056/NEJMoa1001283

27. Siraj MA, Pichon C, Radu A, Ghinea N. Endothelial follicle stimulating hormone receptor in primary kidney cancer correlates with subsequent response to sunitinib. J Cell Mol Med. (2012) 16:2010-6. doi: 10.1111/j.1582-4934.2011.01495.x

28. Siraj A, Desestret V, Antoine M, Fromont G, Huerre M, Sanson $\mathrm{M}$, et al. Expression of follicle-stimulating hormone receptor by the vascular endothelium in tumor metastases. BMC Cancer (2013) 13:246. doi: 10.1186/1471-2407-13-246

29. Planeix F, Siraj MA, Bidard FC, Robin B, Pichon C, Sastre-Garau X, et al. Endothelial follicle-stimulating hormone receptor expression in invasive breast cancer and vascular remodeling at tumor periphery. J Exp Clin Cancer Res. (2015) 34:12. doi: 10.1186/s13046-015-0128-7

30. Lenhard M, Lennerová T, Ditsch N, Kahlert S, Friese K, Mayr D, et al. Opposed roles of follicle-stimulating hormone and luteinizing hormone receptors in ovarian cancer survival. Histopathology (2011) 58:990-4. doi: 10.1111/j.1365-2559.2011.03848.x

31. Heublein S, Vrekoussis T, Mayr D, Friese K, Lenhard M, Jeschke U, et al. Her$2 /$ neu expression is a negative prognosticator in ovarian cancer cases that do not express the follicle stimulating hormone receptor (FSHR). J Ovarian Res. (2013) 6:6. doi: 10.1186/1757-2215-6-6

32. Yang Y, Zhang J, Zhu Y, Zhang Z, Sun H, Feng Y. Follicle-stimulating hormone induced epithelial-mesenchymal transition of epithelial ovarian cancer cells through follicle-stimulating hormone receptor PI3K/AktSnail signaling pathway. Int J Gynecol Cancer (2014) 24:1564-74. doi: 10.1097/IGC.0000000000000279

33. Perales-Puchalt A, Svoronos N, Rutkowski MR, Allegrezza MJ, Tesone AJ, Payne KK, et al. Follicle-stimulating hormone receptor is expressed by most ovarian cancer subtypes and is a safe and effective immunotherapeutic target. Clin Cancer Res. (2017) 23:441-53. doi: 10.1158/1078-0432.CCR-16-0492

34. Poniewierska-Baran A, Schneider G, Sun W, Abdelbaset-Ismail A, Barr FG, Ratajczak MZ. Human rhabdomyosarcoma cells express functional pituitary and gonadal sex hormone receptors: therapeutic implications. Int J Oncol. (2016) 48:1815-24. doi: 10.3892/ijo.2016.3439

35. Pawlikowski M, Winczyk K, Stępień H. Immunohistochemical detection of follicle stimulating hormone receptor (FSHR) in neuroendocrine tumours. Endokrynol Pol. (2013) 64:268-71. doi: 10.5603/EP.2013.0004

36. Sardella C, Russo D, Raggi F, Lombardi M, Urbani C, Brogioni S, et al. Ectopic expression of FSH receptor isoforms in neoplastic but not in endothelial cells from pancreatic neuroendocrine tumors. J Endocrinol Invest. (2013) 36:174-9. doi: $10.3275 / 8472$ 
37. Pawlikowski M, Jaranowska M, Pisarek H, Kubiak R, Fuss-Chmielewska J, Winczyk K. Ectopic expression of follicle-stimulating hormone receptors in thyroid tumors. Arch Med Sci. (2015) 6:1314-7. doi: 10.5114/aoms.2015. 56357

38. Pawlikowski M, Fuss-Chmielewska J, Jaranowska M, Pisarek H, Kubiak R, Winczyk K. Expression of follicle stimulating hormone receptors (FSHR) in thyroid tumours - a marker of malignancy? Thyroid Res. (2015) 8:1. doi: 10.1186/s13044-015-0014-6

39. Liu J, Chen G, Meng X-Y, Liu Z-H, Dong S. Serum levels of sex hormones and expression of their receptors in thyroid tissue in female patients with various types of thyroid neoplasms. Pathol Res Pract. (2014) 210:830-5. doi: 10.1016/j.prp.2014.09.002

40. Pawlikowski M, Radek M, Jaranowska M, Kunert-Radek J, Swietoslawski J, Winczyk K. Expression of follicle stimulating hormone receptors in pituitary adenomas - a marker of tumour aggressiveness? Endokrynol Pol. (2014) 65:469-71. doi: 10.5603/EP.2014.0065

41. Pawlikowski M, Pisarek H, Kubiak R, Jaranowska M, Stępień H. Immunohistochemical detection of FSH receptors in pituitary adenomas and adrenal tumors. Folia Histochem Cytobiol. (2012) 50:325-30. doi: $10.5603 / 17850$

42. Renner M, Goeppert B, Siraj MA, Radu A, Penzel R, Wardelmann E, et al. Follicle-stimulating hormone receptor expression in soft tissue sarcomas. Histopathology (2013) 63:29-35. doi: 10.1111/his. 12135

43. Dankbar B, Sohn M, Nieschlag E, Gromoll J. Quantification of androgen receptor and follicle-stimulating hormone receptor mRNA levels in human and monkey testes by a ribonuclease-protection assay. Int $J$ androl. (1995) 18:88-96. doi: 10.1111/j.1365-2605.1995.tb 00391.x

44. Vannier B, Loosfelt H, Meduri G, Pichon C, Milgrom E. Anti-human FSH receptor monoclonal antibodies: immunochemical and immunocytochemical characterization of the receptor. Biochemistry (1996) 35:1358-66.

45. Karakaya C, Guzeloglu-Kayisli O, Hobbs RJ, Gerasimova T, Uyar A, Erdem $\mathrm{M}$, et al. Follicle-stimulating hormone receptor (FSHR) alternative skipping of exon 2 or 3 affects ovarian response to FSH. Mol Hum Reprod. (2014) 20:630-43. doi: 10.1093/molehr/gau024

46. Tani H, Mizutani R, Salam KA, Tano K, Ijiri K, Wakamatsu A, et al. Genome-wide determination of RNA stability reveals hundreds of shortlived noncoding transcripts in mammals. Genome Res. (2012) 22:947-56. doi: 10.1101/gr.130559.111

47. Moeker N, Peters S, Rauchenberger R, Ghinea N, Kunz C, Moeker N, et al. Antibody selection for cancer target validation of FSH-receptor in immunohistochemical settings. Antibodies (2017) 6:15. doi: 10.3390/antib60 40015

48. Song Y, Wang E-S, Xing L-L, Shi S, Qu F, Zhang D, et al. Follicle-stimulating hormone induces postmenopausal dyslipidemia through inhibiting hepatic cholesterol metabolism. J Clin Endocrinol Metab. (2016) 101:254-63. doi: 10.1210/jc.2015-2724

49. Sun L, Zhang Z, Zhu L-L, Peng Y, Liu X, Li J, et al. Further evidence for direct pro-resorptive actions of FSH. Biochem Biophys Res Commun. (2010) 394:6-11. doi: 10.1016/j.bbrc.2010.02.113

50. Robinson LJ, Tourkova I, Wang Y, Sharrow AC, Landau MS, Yaroslavskiy BB, et al. FSH-receptor isoforms and FSH-dependent gene transcription in human monocytes and osteoclasts. Biochem Biophys Res Commun. (2010) 394:12-7. doi: $10.1016 /$ j.bbrc.2010.02.112

51. Cannon JG, Kraj B, Sloan G. Follicle-stimulating hormone promotes RANK expression on human monocytes. Cytokine (2011) 53:141-4. doi: 10.1016/j.cyto.2010.11.011

52. Tapanainen JS, Aittomaki K, Min J, Vaskivuo T, Huhtaniemi IT. Men homozygous for an inactivating mutation of the follicle-stimulating hormone (FSH) receptor gene present variable suppression of spermatogenesis and fertility. Nat Genet. (1997) 15:205-6. doi: 10.1038/ng0297-205

53. Tang B, Gurpide E. Direct effect of gonadotropins on decidualization of human endometrial stroma cells. J Steroid Biochem Mol Biol. (1993) 47:115-21. doi: 10.1016/0960-0760(93)9 0064-4

54. Hovatta O, Soderstrom-Anttila V, Foudila T, Tuomivaara L, Juntunen $\mathrm{K}$, Tiitinen A, et al. Pregnancies after oocyte donation in women with ovarian failure caused by an inactivating mutation in the follicle stimulating hormone receptor. Hum Reprod. (2002) 17:124-7. doi: 10.1093/humrep/1 7.1.124

55. Popovici RM, Kao LC, Giudice LC. Discovery of new inducible genes in in vitro decidualized human endometrial stromal cells using microarray technology. Endocrinology (2000) 141:3510-3. doi: 10.1210/endo.141. 9.7789

56. Thurston RC, Sowers MR, Sternfeld B, Gold EB, Bromberger J, Chang Y, et al. Gains in body fat and vasomotor symptom reporting over the menopausal transition: the study of women's health across the nation. Am J Epidemiol. (2009) 170:766-74. doi: 10.1093/aje/kwp203

57. Vuorenoja S, Mohanty BP, Arola J, Huhtaniemi I, Toppari J, Rahman NA. Hecate-CGbeta conjugate and gonadotropin suppression shows two distinct mechanisms of action in the treatment of adrenocortical tumors in transgenic mice expressing Simian Virus $40 \mathrm{~T}$ antigen under inhibinalpha promoter. Endocr Relat Cancer (2009) 16:549-64. doi: 10.1677/ERC-0 8-0232

58. Doroszko M, Chrusciel M, Stelmaszewska J, Slezak T, Anisimowicz S, Plockinger U, et al. GnRH antagonist treatment of malignant adrenocortical tumors. Endocr Relat Cancer (2019) 26:103-17. doi: 10.1530/ERC-17-0399

59. Finkelstein JS, Yu EW, Burnett-Bowie SA. Gonadal steroids and body composition, strength, and sexual function in men. N Engl J Med. (2013) 369:2457. doi: 10.1056/NEJMoa1206168

60. Sponton $\mathrm{CH}$, Kajimura S. Burning fat and building bone by FSH blockade. Cell Metab. (2017) 26:285-7. doi: 10.1016/j.cmet.2017.07.018

61. Sowers MR, Greendale GA, Bondarenko I, Finkelstein JS, Cauley JA, Neer RM, et al. Endogenous hormones and bone turnover markers in pre- and perimenopausal women: SWAN. Osteoporos Int. (2003) 14:191-7. doi: 10.1007/s00198-002-1329-4

62. Blair HC, Robinson LJ, Sun L, Isales C, Davies TF, Zaidi M. Skeletal receptors for steroid-family regulating glycoprotein hormones: a multilevel, integrated physiological control system. Ann NY Acad Sci. (2011) 1240:26-31. doi: 10.1111/j.1749-6632.2011.06287.x

63. Drake MT, McCready LK, Hoey KA, Atkinson EJ, Khosla S. Effects of suppression of follicle-stimulating hormone secretion on bone resorption markers in postmenopausal women. J Clin Endocrinol Metab. (2010) 95:50638. doi: 10.1210/jc.2010-1103

64. Uihlein AV, Finkelstein JS, Lee H, Leder BZ. FSH suppression does not affect bone turnover in eugonadal men. J Clin Endocrinol Metab. (2014) 99:2510-5. doi: 10.1210/jc.2013-3246

65. Sanyal A, Hoey KA, Modder UI, Lamsam JL, McCready LK, Peterson JM, et al. Regulation of bone turnover by sex steroids in men. J Bone Miner Res. (2008) 23:705-14. doi: 10.1359/jbmr.071212

66. Crawford ED, Schally AV, Pinthus JH, Block NL, Rick FG, Garnick MB, et al. The potential role of follicle-stimulating hormone in the cardiovascular, metabolic, skeletal, and cognitive effects associated with androgen deprivation therapy. Urol Oncol. (2017) 35:183-91. doi: 10.1016/j.urolonc.2017. 01.025

67. Gao J, Tiwari-Pandey R, Samadfam R, Yang Y, Miao D, Karaplis AC, et al. Altered ovarian function affects skeletal homeostasis independent of the action of follicle-stimulating hormone. Endocrinology (2007) 148:2613-21. doi: 10.1210/en.2006-1404

68. Ritter V, Thuering B, Saint Mezard P, Luong-Nguyen NH, Seltenmeyer Y, Junker U, et al. Follicle-stimulating hormone does not impact male bone mass in vivo or human male osteoclasts in vitro. Calcif Tissue Int. (2008) 82:383-91. doi: 10.1007/s00223-008-9134-5

69. Iqbal J, Sun L, Kumar TR, Blair HC, Zaidi M. Follicle-stimulating hormone stimulates TNF production from immune cells to enhance osteoblast and osteoclast formation. Proc Natl Acad Sci USA. (2006) 103:14925-30. doi: $10.1073 /$ pnas.0606805103

70. Zheng W, Lu JJ, Luo F, Zheng Y, Feng Y, Felix JC, et al. Ovarian epithelial tumor growth promotion by follicle-stimulating hormone and inhibition of the effect by luteinizing hormone. Gynecol Oncol. (2000) 76:80-8. doi: 10.1006/gyno.1999.5628

71. Choi JH, Choi KC, Auersperg N, Leung PC. Gonadotropins activate proteolysis and increase invasion through protein kinase $\mathrm{A}$ and phosphatidylinositol 3-kinase pathways in human epithelial ovarian cancer cells. Cancer Res. (2006) 66:3912-20. doi: 10.1158/0008-5472.CAN-05-1785 
72. Sanchez AM, Flamini MI, Russo E, Casarosa E, Pacini S, Petrini M, et al. LH and FSH promote migration and invasion properties of a breast cancer cell line through regulatory actions on the actin cytoskeleton. Mol Cell Endocrinol. (2016) 437:22-34. doi: 10.1016/j.mce.2016.08.009

73. Wang F, Flanagan J, Su N, Wang LC, Bui S, Nielson A, et al. RNAscope: a novel in situ RNA analysis platform for formalin-fixed, paraffin-embedded tissues. $J$ Mol Diagn. (2012) 14:22-9. doi: 10.1016/j.jmoldx.2011.08.002

74. Yang F, Liu C, Chen D, Tu M, Xie H, Sun H, et al. CRISPR/Cas9loxP-mediated gene editing as a novel site-specific genetic manipulation tool. Mol Ther Nucleic Acids (2017) 7:378-86. doi: 10.1016/j.omtn.2017. 04.018
Conflict of Interest Statement: The authors declare that the research was conducted in the absence of any commercial or financial relationships that could be construed as a potential conflict of interest.

Copyright (C) 2019 Chrusciel, Ponikwicka-Tyszko, Wolczynski, Huhtaniemi and Rahman. This is an open-access article distributed under the terms of the Creative Commons Attribution License (CC BY). The use, distribution or reproduction in other forums is permitted, provided the original author(s) and the copyright owner(s) are credited and that the original publication in this journal is cited, in accordance with accepted academic practice. No use, distribution or reproduction is permitted which does not comply with these terms. 